\title{
Teaching Chemistry in the French Revolution: Pedagogy, Materials and Politics
}

\author{
Bernadette Bensaude Vincent
}

By the end of 1794 - Year III of the revolutionary calendar, the young "one and indivisible" French republic established a Normal School (École normale) to "provide the French people with a system of instruction worthy of its novel destiny." ${ }^{1}$ More concretely the purpose was to train a number of citizens quickly so that they could train the future primary and secondary teachers in all the districts of the French territory. Chemistry was an integral part of the curriculum, which included both science and humanities. The term 'école normale' clearly conveys a project of normalization or standardization of education providing a uniform approach to all the sectors of knowledge previously covered by the Encyclopédie. This teaching institution was dedicated to "shaping the man and the citizen." It was meant to coproduce knowledge and citizenship according to the republican ideals of liberty, equality, and fraternity. Well-trained teachers (instituteurs) would be "capable of being the executives of a plan aimed at regenerating the human understanding in a republic of 25 million people, all of whom democracy rendered equal." ${ }^{2}$

Claude-Louis Berthollet participated in this state initiative to assume his social and political role as a teacher. As one of the supporters of Lavoisier's chemistry and a member of the group of academicians who reformed the

1 Anon., "Arrêté des représentants du peuple près les Écoles normales du 24 nivôse an III de la République française une et indivisible," Séances des Écoles normales (Paris: Imprimerie du Cercle social, 1800-1801). All lessons are now available in print: Jean Dhombres, ed., L'École normale de l'An III. Leçons de mathématiques. Laplace, Lagrange, Monge (Paris: Dunod, 1992); Daniel Nordman, ed., L'École normale de l'An III. Leçons d'histoire, de géographie, d'économie politique. Volney, Buache de la Neuville, Mentelle, Vandermonde (Paris: Dunod, 1994); Etienne Guyon, ed., L'École normale de l'An III. Leçons de physique, de chimie, et d'histoire naturelle. Haüy, Berthollet, Daubenton (Paris: éditions Ens Rue d'Ulm, 2006); Béatrice Didier, Jean Dhombres, eds., L'École normale de l'An III. Leçons littéraires, art de la parole, morale, analyse de l'entendement (Paris: éditions ENs Rue d'Ulm, 2009). On the ambitions of the educational projects of the French Revolution, see Mona Ozouf, L'homme régénéré. Essais sur la Révolution française (Paris: Gallimard, 1989).

2 Debate at the Convention nationale in September 1794 quoted in Jean Dhombres, "Introduction générale," Dhombre, ed., Cours de l'école normale de l'An III, p. 1 (see note 1).

(C) BERNADETTE BENSAUDE VINCENT, 2018 | DOI 10.1163/9789004325562_012

This is an open access chapter distributed under the terms of the CC-BY-NC License. 
chemical language in the $178 \mathrm{os}$, he could be expected to contribute to the national effort of normalization by teaching the new chemistry, known as the "theory of French chemists". Given the synchronism of the chemical and political revolutions, chemistry featured as an ideal discipline to prompt the transformation of the socio-political order by making up citizens capable of transforming natural substances into national resources for the nation's warfare and public welfare.

However Berthollet's chemistry lectures suggest a quite different endeavor. He did not take on the role of spokesman for a chemical community engaged in a deep transformation of this discipline. Far from aiming at stabilizing the new language of chemistry and promoting the theory outlined in Lavoisier's Traité élémentaire de chimie (1789), Berthollet developed personal views about chemical theories and utilitarian applications. He did nothing to spread the gospel of two synchronic revolutions.

This essay stresses the gap between the national aspiration to shape the future citizens of a new sociopolitical order and the pedagogical practice of the chemistry lecturer. While the École normale was meant to instill in children and their teachers the normative frame according to which they should live and work in a republican society, Berthollet's lessons rather aimed at shaping competent citizens by sharing his experience of the world as an expert in chemical theory and arts. While revolutionary education was institutionally projected as possessing a disciplinary power with which to govern both social and material constituents, in Berthollet's design it consisted in transmitting one's own knowledge and expertise in the art of governing the multitude of chemical substances.

The first section of this essay presents the goals and ambitions of the creation of the Normal School in the dual context of the political and chemical revolutions. The second section focuses on the course of chemistry and describes the site, the audience, and what we know about the teacher's performance. In the third section I argue that Berthollet's pedagogical choice expressed his personal vision of chemistry, which deeply differed from Lavoisier's chemistry. It reveals a tension between Berthollet's aspiration to a world ruled by general laws and his concern with exceptions. While he stressed the deductive power of chemical theory for enlightening chemical arts, Berthollet nevertheless focused on anomalies and peculiar circumstances. Berthollet's lessons reflected his own experience of the world as a chemist oscillating between the power of disciplining material substances conferred by chemical theory and the art of paying attention to circumstances. 


\section{Normalizing Science and Education: A Revolutionary Ambition}

The National Convention was a site for legislation intended to discipline society and the economy through the organization of centralized structures and practices of administration and education. It established the Normal School a few months after the end of the Terror, which had generated strong campaigns of slander against scientists. ${ }^{3}$ It was crucial for the young republic to create trust between the elites and the new regime following the dissolution of the Paris Royal Academy of Sciences together with all other academies in 1793 and the execution of Lavoisier together with twenty-one tax collectors of the ancien régime. "The republic has no need of savants" ("la république n'a pas besoin de savants"): although this alleged response of the revolutionary tribunal to Lavoisier's request of a delay of capital punishment proved to be a legend, it certainly expressed the general opinion and fear of the elite who had initially supported the revolutionary movement. In fact the revolutionary government badly needed the knowledge and skills of scientists for warfare. Chemists were mobilized to produce large quantities of hydrogen for balloons, to transform the church bells into canons and to manufacture saltpeter. So pressing was the lack of explosive powder that in February 1794, the French government mobilized leading chemists such as Gaspard Monge, Jean-Henri Hassenfratz, Louis-Bernard Guyton de Morveau, Antoine de Fourcroy and Berthollet to teach French citizens how to collect and process saltpeter in their basements. ${ }^{4}$

In addition to warfare, the young republic needed scientists for the institution of public service in general, and education in particular. The decree creating the Normal School aimed at replacing the educational system, which had been in the hands of the Church during the ancien régime. For this purpose it was crucial to train primary and secondary teachers. The Church educational system had already inaugurated this kind of institution in 1685 with Jean Baptiste de la Salle's Institute of the Brothers of the Christian Schools. The National Convention decreed: "An école normale will be established in Paris where citizens from all parts of the republic already instructed in useful

3 Charles Coulston Gillispie, "Science in the French Revolution," Proceedings of the National Academy 45 (1959): 677-84. Charles Coulston Gillispie, The Edge of Objectivity: An essay in the history of scientific ideas (Princeton: Princeton University Press, 1966).

4 Programmes des cours révolutionnaires sur la fabrication des salpêtres, des poudres et des canons; faits à Paris dans l'amphithéâtre du Muséum d'histoire naturelle et dans la salle des Electeurs ... les 1, 11, 21 ventôse et 5 germinal, zème année de la République française ... par les citoyens Guyton, Fourcroy, Dufourny, Berthollet, Carny, Pluvinet, Monge, Hassenfratz et Perrier, 2nd edition (Paris: Comité de Salut public, 1794). 
sciences will be called in order to learn the art of teaching under the most skilled teachers in all genres." 5

In 1791-92, Nicolas de Condorcet submitted a plan of education to the Legislative Assembly. ${ }^{6}$ It was inspired by the Enlightenment ideal of education for citizenship and Condorcet's conviction that education is the key for the progress of civilization. Although Condorcet's Plan was formally rejected, his ambition to build up a complete national, free and compulsory system of secular schools to provide equal opportunity for all children, served as a guideline for establishing the normal school in 1794. The purpose was to set the standards or norms for a universal plan and methods of education.

The unanimous concourse of wills and the convergence of efforts toward the same goal being the safest guarantee of social order, schools, which are the nurseries of the people bounded to serve the state, must equally provide a uniform instruction, based on fixed and common rules for all teaching houses. ${ }^{7}$

The Normal School founded in 1794 was short-lived but it initiated a process of standardization that would be implemented on its re-opening in 1808 under the First Empire. This process was to be achieved by the students themselves. Those who came to the first training course at the Normal School in Paris had been recruited in each of the eighty seven geographic districts (départements) created in December 1789. On their return to their districts they would create local normal schools to train dozens of primary and secondary teachers.

The Convention wanted to train primary and secondary teachers for the entire territory of the Republic.

5 Article 1 of the Decree of the National Convention, 9 Brumaire An III (October 30, 1794).

6 Nicolas Caritat de Condorcet, Cinq mémoires sur l'instruction publique (1791), new edition Charles Coutel and Catherine Kinzler eds., (Paris: Garnier Flammarion, 1994). See also Keith M. Baker and William A. Smeaton, "The Origins and Authorship of the Educational Proposals Published in 1793 by the Bureau de Consultation des Arts et métiers and Generally Ascribed to Lavoisier," Annals of Science 21 (1965): 33-46. Catherine Kinzler, Condorcet. L'instruction publique et la naissance du citoyen (Paris: Folio/Essais, 1984).

7 This statement about the driving forces behind the creation of the Normal School was formulated on the occasion of its re-opening in 1808 . See the introduction to the edition of the lectures in 1808 quoted by Guyon, ed., L'École normale de l'An III, p. 3 (see note 1): “Le concours unanime et uniforme des volontés, la réunion des efforts vers un même but étant le plus sûr garant de l'ordre social, les écoles, qui sont les pépinières des hommes destinés à servir l'Etat, doivent également offrir une instruction uniforme, basée sur des règles invariables et communes à toutes les maisons d'enseignement." 
Such is the goal of the institution of the écoles normales. In other schools, only the various branches of human knowledge are taught; in the écoles normales, one will teach the most useful knowledge of each kind and insist on the method of exposition. This will essentially distinguish the écoles normales; this will fulfill their denomination. ${ }^{8}$

In keeping with the previous systematizations of natural history and chemical languages and the simultaneous on-going project of standardization of weights and measures, the normal schools standardized both the contents and the methods of teaching. The contents were encyclopedic. According to Condorcet's grand views, all citizens had to be taught how to use reason in order to overcome prejudices due to ignorance and superstition, to know their rights and how to exercise them, as well as how to manage their household and to advance the arts for national welfare. ${ }^{9}$ Similarly in his lectures on physics, René-Just Haüy insisted that primary teachers needed a broad instruction in order to eradicate the prejudices spread by ordinary people, the "vulgar". They had to acquire a bird's-eye view of the contents "in order to distinguish the most direct and easiest route from among all those leading to the targeted goal."10

The Normal School recruited the leading figures of the former academies to deliver an up-to-date survey of all the knowledge embedded in Diderot and D'Alembert's Encyclopédie. It also clearly recommended a linkage between science and arts in education and the concern for public utility. However, the revolutionary Normal School departed from Diderot's Encyclopédie in adopting a disciplinary division of knowledge like the Encyclopédie méthodique." The introductory lessons carefully delineated the contemporary - albeit practically contested - boundaries between physics, chemistry, and natural history, and tried to inculcate them in the future teachers' minds. ${ }^{12}$ Natural sciences

Arrêté du 24 nivôse an II, quoted in Guyon, ed., L'École normale de l'An III, p. 33 (see note 1).

$9 \quad$ Nicolas Caritat de Condorcet, Esquisse d'un tableau des progrès de l'esprit humain (Paris: Au bureau de la bibliothèque choisie, 1795) Engl. Transl. J. Barraclough, Sketch for a historical picture of the progress of the human mind (London: William Clowes and Sons, 1955), 182-184.

10 René Just Haüy, 3rd lecture, in Guyon, ed., L'École normale de l'An III, p. 61 (see note 1).

11 Charles-Joseph Panckoucke ed., Encyclopédie méthodique par ordre de matières par une Société de gens de Lettres, de Savans et d'Artistes (Lille: Librairie Panckoucke, 1782-1832); Claude Blanckaert, Michel Porret, eds., L’Encyclopédie méthodique, 1782-1832. Des Lumières au positivisme (Genève: Librairie Droz, 2006).

12 See René-Just Haüy and Berthollet's first lectures, in Guyon, ed., L'École normale de l'An III, pp. 44 and 256 (see note 1 ). 
were essentially promoted for the enlightenment of workshop practices from a utilitarian perspective.

The project further entailed standardizing the method of learning. This was first to be achieved by teaching all subjects according to the "method of analysis", the method derived from algebra recommended by Etienne Bonnot de Condillac. ${ }^{13}$ In relation to empirical data, the standard method was inspired by a kind of vulgate of Newton's method. Hypotheses were not banned but strictly confined to predictions; theories, clearly distinguished from "systems", could play a key role because they subsume a large number of particular phenomena under one single general law.

To sum up this section, the educational program of the Normal School of Year III was part of the political agenda of the French Revolution. It was one aspect of a huge and multifaceted effort of standardization aimed at making a homogeneous republican society. This effort encompassed the constitution of a national territory divided into 89 administrative units (départements) and the standardization of weights and measures thanks to the institution of republican units of measurement (the metric system). The disciplinary power of these political and institutional measures had to be reinforced by education. Pedagogy and epistemology would shape the future citizens of the French Republic. The academic elites mobilized in the Normal School were expected to contribute to this national effort with their own sense of disciplinarity.

\section{Actual Practices: Site and Courses}

In January 1795,1400 citizens selected to become primary and secondary teachers came to Paris from all over the country for an intensive four-month course. The training included mathematics, physics, natural history, history, geography, political economy, literature, and what is today known as rhetoric (art du discours), ethics (morale) and philosophy (analyse de l'entendement). The contrast is striking between the ambition of the program and the time allocated:

13 William Albury, "The Order of Ideas: Condillac's method of analysis as a political instrument in the French revolution," J.A. Schuster, R. Yeo, eds., The Politics and the Rhetoric of Scientific Method. Historical studies (Dordrecht: Reidel, 1986), 203-226. Lissa L. Roberts, "Condillac, Lavoisier, and the instrumentalization of science," Eighteenth-Century, Essays and Interpretation 33 (1992): 252-271. Marco Beretta, The Enlightenment of Matter (Sagamore Beach: Science History Publications, 1993). Bernadette Bensaude Vincent, "Lavoisier, lecteur de Condillac," Dix-Huitième Siècle 42 (2010): 49-65. 
less than a semester from January 20 to May 15, 1795. The winter season being extremely cold, the circumstances were not ideal.

The course included twelve to sixteen sessions per subject, with an average of two to three lectures on each subject per décade (the ten day week of the revolutionary calendar) every day except on the fifth and tenth day between 11am and $2 \mathrm{pm} .{ }^{14}$ The sessions took place in a large auditorium of the former Jardin du Roy, renamed Jardin des plantes. ${ }^{15}$ The auditorium, being too small to accommodate 1400 people, was uncomfortable and on some occasions the attendance became irregular and sparse. ${ }^{16}$

Well-trained stenographers took the minutes of each lecture in shorthand and transcribed them. The transcriptions were revised by the professors, then printed and circulated among the audience. For a number of subjects, in particular chemistry, the published version of the oral lectures delivered in 1795 included an additional lecture delivered in 1801 for updating the contents. More than half of the pages of the printed course were devoted to scientific subjects, although rhetoric got the most number of pages of any single discipline (eighteen percent of the whole). Among the scientific disciplines mathematics received many more than chemistry (sixteen percent versus ten percent).

The students of the first Normal School had been selected on the basis of unclear criteria. They had to be well educated in all subjects, but it seems that their political inclinations also mattered a lot. They were preferably young but half of them had teaching experience, including a good proportion of clergymen. Eighty percent of them became teachers in the écoles centrales (high schools) created by a decree in October 1795. For instance, Antoine Libes (17521832), who had taught physics at the collège (high school) of Toulouse, would later get the chair of experimental physics and chemistry at the École centrale of the Saint-Antoine suburb in Paris. So too did he go on to author a threevolume Traité élementaire de physique (1801) and a Histoire philosophique des progrès de la physique (1810).

The lecturers were selected from among the leading figures of science and humanities, the members of the former academies that had been abolished by a revolutionary decree in 1793. Most of them - Monge, Haüy, Bernardin de St

14 École normale supérieure, Le Livre du Centenaire. Edition du bicentenaire (Paris: Presses de l'École normale supérieure, 1994); Paul Viallaneix and R. Elmoznino eds., L'apprentissage du savoir savant (Paris: PUF, 1995).

15 Yves Laissus, Le Muséum national d'histoire naturelle (Paris: Gallimard, 1995). Stéphane Deligeorges, Alexandre Gady et Françoise Labalette, Le jardin des plantes et le Muséum national d'histoire naturelle (Paris: Monum, 2004).

16 Dominique Julia, "L'École normale de l'an III: bilan d'une expérience révolutionnaire," Revue du Nord 78 (1996): 853-886. 
Pierre - had already taught in higher education institutions. In this respect, Berthollet was an exception. Trained in medicine in Torino he became the private physician of the lover of the Duc d'Orléans on his arrival in Paris in 1772 and for fifteen years he conducted chemical research in the duke's private laboratory. ${ }^{17}$ Like many chemists of the time, he collected airs and investigated their chemical properties. ${ }^{18}$ In 1779, he became docteur-régent of the Paris faculty of medicine. He entered the Académie des sciences as adjunct chemist in 1780 where he regularly interacted and collaborated with Lavoisier. Typical of chemists' and chemistry's fluid movement between material and knowledge production at that time, he became Director of Dyes at the Gobelins Royal Manufacture in 1784 . This position implied that he had to visit the workshops to explore dyeing practices and to write a treatise on this art. It was in this context that he invented a bleaching process (involving what later came to be known as chlorine) and published the Eléments de l'art de la teinture in ${ }^{1791 .}{ }^{19}$ Berthollet was thus not only a leading figure in academic chemistry but also an expert in chemical arts. However, unlike his colleagues at the Normal School, he had no teaching experience prior to the revolutionary course on saltpeter he co-taught and his course at the Ecole des travaux publics.

According to the testimonies of some students of the Normal School, Berthollet was not a brilliant teacher. Joseph Fourier, who later became a famous physicist, wrote in 1785 :

Berthollet is the greatest chemist of today, whether in France, or abroad; he is not aged (forty-seven years) and with an ordinary look. He speaks with the most extreme difficulty, hesitates and repeats ten times the same words in a sentence and he seems embarrassed in the least details of experiments. ${ }^{20}$

This view is confirmed by another testimony from Jean-Michel RaymondLatour, who praised Berthollet as "the Newton of transcendental chemistry," but remembered his poor teaching performances. He remembered especially

17 Michelle Sadoun Goupil, Le chimiste C.L. Berthollet, 1748-1822, sa vie, son oeuvre (Paris: Vrin, 1977).

18 Claude-Louis Berthollet, Observations sur l'air (Paris: Firmon Didot, 1776).

19 Agusti Nieto Galàn, Colouring Textiles. A history of natural dyestuffs in industrial Europe (Boston: Boston Studies in the Philosophy and History of Science, 2001).

20 Joseph Fourier, letter dated from March 18, 1785, quoted by Sadoun Goupil, Le chimiste Claude-Louis Berthollet, p. 37 (see note 17). 
that when Berthollet presented his own work on ammonia, he was so shy and embarrassed that Monge had to replace him for the rest of the lecture. ${ }^{21}$

All lecturers at the Normal School had to follow three specific rules to conform to the novel republican pedagogy, which broke with the traditional dogmatic style of teaching based on authority. First, lecturers should not read their lectures. Second, they were asked to focus on the basics of their subject matter, the idea being that knowledge for all would reduce social inequalities. Most importantly, entire sessions were to be dedicated to debates with the audience. The printed transcriptions of these special sessions show that the debates were not just meant for clarifying basic concepts. Some of the students who had teaching experience did not hesitate to discuss the professors' theoretical and pedagogical choices and even criticized them.

The printed version of the oral lectures, however, also demonstrates that the lecturers did not strictly follow the revolutionary guidelines. Indeed, in their introductory lectures they claimed that scientific theories were keys for the progress of human welfare and that a good instruction should proceed gradually from elementary notions to more complex ones. However these were essentially rhetorical claims. The messages delivered in some of their lectures could be summarized by the motto. "Follow what I say. Do not follow what I do."22 For instance, while Haüy emphasized the importance of mathematics for physics he nevertheless adopted a descriptive approach to natural phenomena and insisted on the practice of experimental methods. ${ }^{23}$ Louis Jean-Marie Daubenton who was both a professor and former director of the Jardin du Roy was extremely concerned with didactics, but his lectures were full of digressions and details, which in some cases obliterated their theoretical consistency. ${ }^{24}$ More generally, the transcribed lectures suggest that the professors struggled to resolve the tension between two conflicting demands: to promote a new didactics of science and to provide a review of the most recent

21 Jean-Michel Raym
son,1836), 51-52.

24

Guyon, ed., L'École normale de l'An III, p. 3 (see note 1).

For instance Haüy's second lecture on the general properties of bodies (impenetrability, divisibility, mobility, gravity), presented the experiments conducted for determining the republican kilogram. Guyon, ed., L'École normale de l'An III, pp. 50-55 (see note 1); The fourteenth lecture on electricity consisted in a detailed description of Coulomb's experiments. Ibid., pp. 174-184.

For instance in his first lecture meant to define the object and limits of natural history, Daubenton interrupted the presentation of veterinary art with a lengthy description of the efforts of acclimatization of useful animals. Guyon, ed., L'École normale de l'An III, pp. 420-22 (see note 1). 
developments in their field. In other words, the pedagogical practice of the teachers responded to the requirements of their respective discipline more than to the centralizing policy demands to discipline future citizens. The constraints of individual scientific disciplines and personal styles of individual lecturers clashed with the overall disciplinary framework that was supposed to create a new sociopolitical order.

\section{Disciplinary Power or Art of Governance?}

In January 1795 Lavoisier, who had been among the victims of the Terror in May 1794, could not deliver the chemistry lectures. This was unfortunate for the Normal School because his view of chemistry matched its pedagogical style. Lavoisier, as it is well known, promoted his own theory as a 'revolution' in chemistry. ${ }^{25}$ Also well known is that contemporary historians of chemistry legitimately question whether the term 'revolution' is warranted for various reasons, including the Kuhnian view of scientific revolutions as involving paradigm shifts. ${ }^{26}$ However neither this Kuhnian definition of the term 'revolution' nor the idea that it necessarily involved a radical break with the past prevailed at the end of the eighteenth century. ${ }^{27}$ In a sense, as I have argued elsewhere, Lavoisier's own revolutionary ambition and the subsequent controversy that he sparked together with the reform of the chemical language contributed to stabilizing the current meaning of the phrase 'scientific revolution'.28 In any event, the elements that he and his champions viewed as constituting the 'chemical revolution' served the project of normalization carried out by the École normale in three ways. First, Lavoisier's method of balancing the inputs and outputs of chemical reactions could be perceived as a kind of disciplinary

25 In 1772, Lavoisier deposited a sealed note at the Paris Academy of Sciences describing the experiments of calcination, which led him to question the phlogiston theory and mentioning that they might bring about "a revolution in physics and chemistry." Henry Guerlac, Lavoisier- The Crucial Year: The background and origin of his first experiments on combustion, in 1772 (Ithaca, NY: Cornell University Press, 1961).

26 See for instance Ursula Klein, "A Revolution that Never Happened," Studies in History and Philosophy of Science 49 (2015): 80-90.

27 I. Bernard Cohen, Revolution in Science (Cambridge MA: Harvard University Press, 1985). Rolf Reichardt Rolf, H.J. Lüsebrink, "Révolution à la fin du $18^{\mathrm{e}}$ siècle. Pour une relecture d'un concept-clé du siècle des Lumières," Mots 16 (1988): 35-68. Alain Rey, Révolution: Histoire d'un mot (Paris: Gallimard, 1989).

28 Bernadette Bensaude Vincent, Lavoisier. Mémoires d'une révolution (Paris: Flammarion, 1993). 
power over both materials and the minds and bodies of those who were charged with performing these balancing acts. Whether or not Lavoisier actually matched his claims of quantitative precision, he used them as a rhetorical argument to convert his fellow chemists to his views as instantiated in his spectacular experiment on water, which determined Berthollet to rally to him. ${ }^{29}$ Second, the reform of chemical nomenclature provided a revolutionary model of standardization; the new language of chemistry submitted to the Paris Academy in 1787 by Guyton de Morveau, Lavoisier, Fourcroy and Berthollet was an artificial language, breaking with the language forged by those who had worked with chemical substances over many centuries. ${ }^{30}$ The new language was promoted as a way to prompt a radical break with the past and in particular with the phlogiston theory, although the appropriation of this nomenclature by European chemists did not always match this ideal. ${ }^{31}$

Third and more importantly, the normalization of linguistic habits could be used as a prelude to the normalization of the republican educational system. Lavoisier's Traité élementaire de chimie promoted a new pedagogy of chemistry based on Condillac's claim that words, facts and ideas were the three ingredients of the formation of ideas in children's minds. Lavoisier presented his Traité as an extension of the memoir on the reform of nomenclature:

The impossibility of separating the nomenclature of a science from the science itself is owing to this, that every branch of physical science must consist in three things: the series of facts which are the objects of the science; the ideas which represented these facts; and the words by which these ideas are expressed. Like three impressions of the same seal, the word ought to produce the idea, and the idea to be a picture of the fact. And as ideas are preserved and communicated by means of words, it necessarily follows that we cannot improve the language of any science without at the same time improving the science itself. [...] When we

29 See Bernadette Bensaude Vincent, "Between Chemistry and Politics: Lavoisier and the balance," Eighteenth-century, Essays and Interpretation, 33 (1992): 217-237. On the challenges to Lavoisier's precision see Jan Golinski, "Fit Instruments': Thermometers in eighteenth-century chemistry," Frederic L. Holmes and Trevor H. Levere, eds., Instruments and Experimentation in the History of Chemistry (Cambridge, MA: MIT Press, 2000), 185-210. Louis-Bernard Guyton de Morveau, Antoine Lavoisier, Claude-Louis Berthollet, Antoine de Fourcroy, Méthode de nomenclature chimique (Paris: Cuchet, 1787), new edition (Paris: Seuil, 1994).

Bernadette Bensaude Vincent and Ferdinando Abbri, eds., Lavoisier in European Context. Negotiating a new language for chemistry (Sagamore Beach: Science History Publications, 1995). 
begin the study of any science, we are in a situation respecting that science similar to children's and the course by which we have to advance, is precisely the same, which Nature follows in the formation of their ideas. $^{32}$

According to this formulation, learning - the formation of complex ideas in children's minds - results from the association of simple sensations just as chemical compounds are formed through the association of simple substances and compound words by the addition of simple words. In Lavoisier's view, the material elements of chemistry (simple bodies) were one and the same as chemistry's pedagogical elements. From the simple to the complex, the order of learning mirrored the order of material composition in nature. ${ }^{33}$ Thus chemistry could elegantly solve the dilemma that lecturers at the Normal School had to face: promoting a new didactics of science and at the same time providing a review of the most recent advances in their field.

Yet Berthollet did not follow this elegant pattern. On the one hand, he deliberately refused to give an elementary course. He assumed that his mission was to provide a survey of recent advances in chemistry. The future teachers in the audience were supposed to rephrase them later into a more didactic form. Indeed, Berthollet recommended proceeding from the simple to the complex in elementary courses of chemistry, but he clearly stated that he was not in the same situation as teachers addressing an audience of pupils. On the other hand, he did not follow Lavoisier's metaphysical assumption that the formation of ideas from simple to more complex ones was the mirror image of the composition of words in human language or of the formation of compound substances in nature. He firmly rejected the parallel between the order of learning and the order of nature, which was the basic pre-assumption of Lavoisier's revolutionary pedagogy. Berthollet claimed instead that natural phenomena should be approached from various standpoints in order both to facilitate the organization of ideas in the pupils' minds and to develop further investigations. To the linear analytical order (from the simple-to-the-complex), he preferred displaying a broad spectrum of perspectives on each subject. Lavoisier, for example, had refused to discuss affinities in his Traité élémentaire, arguing that the subject was too difficult and required too many pre-

32 Antoine Lavoisier, Traité élémentaire de chimie (Paris: Cuchet, 1789); Elements of Chemistry, translated by R. Kerr (Edinburgh : W. Creech, 1790), xiii. Bernadette Bensaude Vincent, "A View of the Chemical Revolution Through Contemporary Textbooks: Chaptal, Lavoisier, Fourcroy," British Journal for the History of Science 23 (1990): 435-6o. 
conceptions to be included in an elementary course of chemistry. ${ }^{34}$ Berthollet, contrariwise, dedicated his first lecture to the theory of affinity, based on his own claim that affinities constituted the core concept of chemistry. His justification was that their attractive action balanced by the repulsive force of caloric provided "the basic principle of all chemical phenomena." The description of the properties of simple substances and their compounds thereby entailed the application of this general principle. ${ }^{35}$

The structure of Berthollet's course (table 10.1) reveals both an interest in the theoretically arcane and a concern for practical aspects of the social practice of chemistry. In his first programmatic lecture Berthollet advocated the view of technological applications and improvements deduced from theoretical understanding. He intended to provide the broad deductive framework on which basis future teachers would have to develop more particular aspects according to their audience. But in none of the following lectures did he deduce practical applications from theory.

Strikingly, far from dogmatically imposing the revolutionary norms on chemistry, Berthollet demanded that his audience be able to interpret knowledge by themselves. In particular, he did not devote a single lecture to the new language of chemistry. His silence is all the more striking since he was a member of the group of chemists who had reformed the language of chemistry in $1787 .^{36}$ The Normal School was an ideal place to spread the new nomenclature and the underlying "theory of French chemists." Judging from the transcription of the first session of debates, such was the expectation of a number of the students in the audience. While Berthollet announced that the session would be devoted to a discussion of chemical attractions, Etienne-Bernard Guillemet from the district of Besançon opened the debate with this critical remark:

Would it not have been more appropriate, or would it not be more appropriate, before proceeding further in your lectures, to talk about the words and rules on which the new chemical nomenclature is based? When one has to talk about a new theory, it is necessary to render the adopted

34 Lavoisier, Traité élémentaire de chimie (see note 32 ).

35 Berthollet, in Guyon, ed., L'École normale de l'An III. Leçons de physique, de chimie, d'histoire naturelle, p. 109 (see note 1).

$36 \quad$ Berthollet was in fact the first chemist who adopted Lavoisier's oxygen theory. In 1785 he used it to account for the formation of dephogisticated marine acid (future chlorine) in reacting manganese dioxide on marine acid (future chlorhydric acid). In 1787 he joined Guyton de Morveau, Lavoisier and Fourcroy to compose the Méthode de nomenclature chimique. In 1789, he was part of the editorial committee of the Annales de chimie, a new journal promoting the antiphlogiston theory. 
TABLE 10.1 Berthollet's Chemistry Course at the École normale de l'An III

First Lecture: 6 Pluviôse an III (January 26, 1795)

- Order to be followed in an elementary course

- Indispensable preliminary: chemical attraction or affinity

Second Lecture: 7 Pluviôse an III (January 27, 1795)

- Anomalies in the affinities

Third Lecture: 22 Pluviôse an III (February 10, 1795)

- Nature and properties of heat: caloric and its action presented through their analogy with dissolutions

First Debate: 27 Pluviôse an III (February 15, 1795)

- On nomenclature, on the laws of affinities, and on phlogiston as well as caloric

Fourth Lecture: 2 Ventôse an III ( February 20, 1795)

- The chemical action of light

Second Debate: 7 Ventôse an III (February 25, 1795)

- On heat and light

Fifth Lecture: 12 Ventôse an III (March 2, 1795)

- Analysis and synthesis of water

Sixth Lecture: 22 Ventôse an III (March mars, 1795)

- Carbonic gas

Seventh Lecture: 2 germinal an III (March 22,1795)

- Composition and properties of combustible bodies; their domestic applications

Eighth Lecture: 12 Germinal an III (April 1, 1795)

- Niters and saltpeters

Ninth Lecture: 22 Germinal an III (April 11, 1795)

- Oxygenated muriatic acid

Tenth Lecture: 2 Floréal an III ( April 21, 1795)

- Chemical properties of atmospheric air

Eleventh Lecture : 12 Floréal an III (April 31,1795)

- Hydrogen combinations: ammonia, action of electricity on various substances

Twelfth Lecture: 22 Floréal an III ( May 11, 1795)

- Acidity: influence of oxygen and its limits

Additional Lecture: 21 Prairial an IX (June 10, 1801)

- Further thoughts about chemical action in gas, plants and animals 
phrases perfectly intelligible, in establishing, prior to using them, the rules of the recent convention, which alone had imagined them. I know that you suppose elementary notions of chemistry in the discussion; but one can have these notions and ignore the meaning of carbonic acid, bombiate carbonate, etc. I will therefore ask you whether it would not be more appropriate to say a few words about the rules of this convention. Your lecture would be more successful, and fruitful.... ${ }^{37}$

Guillemet rightly expected rules in order to extend the process of normalization of chemistry in his own teaching. The emphasis on the term 'convention', which had a clear political connotation at the time of the National Convention, suggests a close association of the chemical revolution and the political revolution. After the end of the Terror fighting external and internal enemies no longer was a priority. The time had come to explain clearly the foundations of the new sociopolitical order. Such was Guillemet's expectation: a revolutionary teacher had to explain clearly the meaning and foundations of the new linguistic order. Berthollet ignored the criticism and answered that the new language was already embedded in the exposition of the recent advances in chemistry. It would suffice, he replied, to juxtapose the old and the novel denominations in the rest of his lectures.

Berthollet did not care to normalize chemistry. Quite the contrary, he was interested in anomalies. Following the first lecture on the theory of elective affinities and the construction of affinity tables, he devoted an entire lecture to the cases that opposed the order of affinities in the tables. He thus detailed a number of reactions where the products reacted with reagents and offered two possible explanations for such anomalies: either a variation in temperature or the proportion of substances. ${ }^{38}$ His take-home message to the future instructors was that they should pay attention to the circumstances of reaction. He repeatedly emphasized their peculiarity more than their conformity with the general rule. This attention to the local and particular circumstances would lead him to revise the standard theory of affinity in his Essai de statique chimique (1803) and to oppose Joseph Proust regarding the general law of fixed proportions. ${ }^{39}$

Berthollet, First debate, 27 pluviôse/February 15 in Guyon, ed., L'École normale de l'An III. Leçons de physique, de chimie, d'histoire naturelle, p. 275 (see note 1).

38 See Pere Grapi and Merce Izquierdo, "Berthollet's Conception of Chemical Change in Context," Ambix 44 (1997): 113-30.

39 Kiyohisa Fujii, "The Berthollet-Proust Controversy and Dalton's Atomic Theory, 18001820," British Journal for the History of Science 19 (1986): 177-200. 
More broadly Berthollet did not use the opportunity of this course to spread the "theory of French chemists". He surveyed state of the art European chemistry and downplayed the divide between so-called 'phlogistonist' and 'antiphlogistonist' chemists. Strikingly his lectures portrayed chemistry as an international and communal science, a position that opponents to the 'new chemistry' had sought to use as a foil to what they saw as its imperialistically French character. While he hardly mentioned his own work and contributions (on ammonia, for instance), he nevertheless ventured personal theoretical views in the twelfth lecture on acidity. Here he began with two examples that instantiated Lavoisier's theory of acids, followed by the presentation of oxygenated compounds without acidic properties and one acid that did not contain oxygen. Berthollet clearly expressed his own view: "This is a question on which I disagree with most chemists." ${ }^{\text {40 }}$

\section{Conclusion}

This essay presented Berthollet's lectures at the École normale de l'An III as one face of chemistry in the public sphere, which has been eclipsed by the standard narratives of the chemical revolution shaped by Lavoisier. Berthollet's lectures clearly indicate that there was no uniform paradigm of chemistry even among the French antiphlogistonist school. He disagreed with Lavoisier not only about theoretical aspects (such as the nature of acids) but also about the moral economy of chemistry. ${ }^{41}$ The values underlying Lavoisier's chemistry were simplicity, standardization, abstraction from local contexts and circumstances. By contrast, Berthollet put the emphasis on non-standard cases and local circumstances. Through his engagement in both the chemical and the French revolutions, Berthollet was trying to promote an alternative model of order - one that would take into account the complexities of the real world rather than promoting an ideal of normality.

Although Lavoisier's chemistry provided a form of disciplinary power over materials and language, which was in full agreement with the project of normalizing science and education, Berthollet promoted chemistry as an art of circumstances requiring attention and personal experience. To the discipli-

40 Berthollet, Premier débat, 27 pluviôse/February 15 in Guyon, ed., L'École normale de l'An III. Leçons de physique, de chimie, d'histoire naturelle, p. 350 (see note 1).

41 The moral economy of science in Lorraine Daston's sense is "a balanced system of emotional forces, with equilibrium points and constraints." Lorraine Daston, "The Moral Economy of Science," Osiris 10 (1995): 2-24, 2. 
nary power of chemistry balancing chemical equations and ruling all chemical arts, he preferred a governance of materials and reactions based on negotiations with their peculiar behaviors in specific circumstances. It is not that Berthollet was against all systematic order. Rather for him disciplining materials by submitting them to the rule of general laws did not make sense as long as it introduced an arbitrary decision of minimizing the significance of exceptions. In his view anomalies were interesting and informative as much as the standard cases. In more general terms, Berthollet was against the revolutionary plea for normalization because it entailed a process of abstraction and idealization of the actual behavior of materials in the real world. He sought a more inclusive order that would take the particularities of ambient circumstances into account. In recognizing the mundane complexities of the material world, he invited future citizens to negotiate between the goal of disciplining knowledge, on one hand, and both nature and society on the other.

Lavoisier's analytic-synthetic ideal of standardized chemical substances prevailed for most of the nineteenth century, whereas Berthollet's ideal was eclipsed. The Normal School was globally regarded as a failure because "the professors' lessons were academic courses rather than lectures appropriated for instruction." ${ }^{22}$ Under Napoléon's empire, teachers were trained at the university: they had to attend courses at the Collège de France, the École polytechnique and the Muséum d'histoire naturelle. When the Normal School was fully re-established in 1830 by King Louis-Philippe the program of the chemistry course mainly dealt with stoichiometric compounds although it maintained a first lesson dedicated to "molecular attraction" and affinity. ${ }^{43}$ It included one laboratory class per week but virtually no practical recipes for preparing useful compounds. For many decades, only "daltonide" compounds were investigated, whereas "berthollide" non-stoichiometric compounds and equilibrium reactions were ignored until the 1870s. Only under the Third Republic did chemists face the challenge of normalizing the berthollides, of ruling chemical equilibrium with the mass action law and Henry Le Chatelier's law. However, in advocating the application of Taylorism to laboratory research, Le Chatelier extended the ideal of normalization to all practices of chemistry. ${ }^{44}$ Definitely, Berthollet's lessons of chemistry failed to shape the future generations of French chemists!

\footnotetext{
42 Victor Cousin, in École normale. Règlements, programmes et rapports (Paris: Hachette, 1837), p. 4.

43 Programme du cours de chimie, 1st et 2nd semester in ibid., p. 50-56.

44 Henry Le Chatelier, Science et industrie (Paris: Flammarion, 1925).
} 


\section{Acknowledgments}

I am indebted to Patrice Bret and Pere Grapi who collaborated with me for the edition of Berthollet's lecture in Etienne Guyon ed. L'École normale de l'An III. Leçons de physique, de chimie, et d'histoire naturelle. Haüy, Berthollet, Daubenton. (Paris, éditions ENs Rue d'Ulm, 2006). I also wish to thank Lissa Roberts for her critical comments on earlier versions of this essay. 